\title{
Assessment of a Writing Workshop Model for First-Year Engineering Stu- dents
}

\section{Dr. Patricia R Backer, San Jose State University}

Dr. Backer been a faculty at SJSU since 1990 and held positions as an assistant professor, associate professor, professor, department chair, and director. Since coming to San Jose State University in 1990, I have been involved in the General Education program. Currently, Dr. Backer serves as the PI for two SJSU grants: the AANAPISI grant and the Title III Strengthening grant both from the U.S. Department of Education. 


\title{
Improving the Writing Skills of Engineering Students: Assessment of a Writing Workshop Model
}

\begin{abstract}
This Evidence Based Practice paper will report on a multi-year project to improve the writing skills of engineering freshmen at San José State University (SJSU). For the last ten years, the college has offered an optional class to students who are not proficient in writing. Students can enroll in a one-unit lab class as many semesters as they wish to get practice in writing. The goal is to provide students with weekly writing activities that include: instruction in basic grammar, proofreading, and editing. In addition to study and practice exercises, students in this writing workshop have writing assignments, which provide practice in using correct grammar, spelling, punctuation, sentence structure, and paragraph structure. Students have the opportunity to develop technical communication skills through written assignments such as memos, letters, and reports.
\end{abstract}

For three years, the CoE has selected freshmen from each entering class as the pilot group and an additional 50 matched students as the comparison group. These students were selected based on their English Placement Test (EPT) scores. The EPT is designed to assess the level of reading and writing skills of entering lower-division students so that they can be placed in appropriate English composition courses. This paper will compare the achievement of the students in the writing workshops with other English-remedial students at SJSU. Introduction

In Fall 2011, SJSU received a U.S. Department of Education grant, AANAPISI, to improve the writing skills of Asian-American students at SJSU. This grant has several focus areas, one of which is the improvement of writing and writing instruction in General Education (GE) classes.

A significant percent of SJSU's incoming freshmen are remedial in English or mathematics. Per CSU policy, students must clear their remedial status within one year or they are disenrolled from the CSU. A look into retention rates shows that there is a higher attrition among remedial students than their non-remedial peers. Also, the time to graduation is typically lengthened up to two years for students who need remedial classes.

Many of these remedial students are high need Generation 1.5 students-U.S. educated English learners. At SJSU, they struggle to complete their English and writing requirements, requirements meant for their native English peers. Often, these struggles impact their retention and graduation rates from SJSU. The challenges presented by this complicated skill set in Generation 1.5 students can be seen most clearly in English writing, a critical competency for academic success at SJSU which encompasses retention and graduation. According to Singhal [1], high needs Generation 1.5 students have unique needs in the areas of academic writing; in particular, these students need to develop their mastery of academic literacy. Literacy is not only the ability to read and write but it also includes "the ability to use critical thinking or higher order thinking skills, communication skills, and research skills.”

The content of ENGR 81W focuses on a progressive instruction and practice in the crucial areas of academic writing [2] so that our students will be prepared to apply academic English to their oral and written communication. For this work, we have built upon the Commanding English 
program from the University of Minnesota (UM) and adapted it for the high needs of Generation 1.5 students at SJSU [3]. This paper will compare the two-year retention and achievement rates of students who took Engr 81W with those who did not.

\section{Review of Literature}

The term "Generation 1.5" evolved out of immigration studies that analyzed the social environments of Southeast Asian children as they adapted to life in the U.S. after the Vietnam war [4]. "First generation" immigrants are people in the U.S. who grew up in another country while "second generation" has been used to refer to the U.S. born children of immigrant parents. Originally, Generation 1.5 is defined as the generation of immigrant students who came to the United States as children (or young adults) and display characteristics of both first- and secondgeneration immigrants in terms of educational background and language acquisition. Now, the term "Generation 1.5" has been expanded to characterize both people who emigrated to the U.S. as young children and children who live dual cultural lives in the U.S. These are students who home language is not English but who have had most of their education in the U.S. Generation 1.5 students constitute a significant, and increasing portion, of our student body at SJSU. An analysis of data from the 2000 U.S. Census by Rumbaut [5] found that Generation 1.5 members were the least linguistically assimilated to the U.S. "Between 1979 and 2008, the number of school-age children (children ages 5-17) who spoke a language other than English at home increased from 3.8 to 10.9 million, or from 9 to 21 percent of the population in this age range” [6] In Santa Clara County, the home of SJSU, the number of non-English speaking children is even higher than the national averages. 25.9\% of K-12 students reported a home language other than English in 2008 [7], making them part of Generation 1.5.

Generation 1.5 individuals are not recent immigrants or mainstream American students. Rather, Generation 1.5 is characterized by a variety of linguistic attributes. For instance, some may see themselves as "bilingual" but they may feel inferior in their command of English. Other Generation 1.5 students appear "fluent" in English conversation but have serious deficiencies in their writing [8]. This group experiences a long, drawn out (and volatile) process of English competence (back and forth, periods of progress, backsliding) and may not even have writing literacy in their language [9][10][4][8]. Thus, Generation 1.5 students are not like international students; they do not have a basis of comparison for one language system with complete fluency in oral and written skills in their first language like international students do. Instead, they are either trying to learn English and also learn how to read and properly speak their first language; or they speak English well but struggle in writing English and learning/speaking their first language in the formal manner [11][12][13]. Generation 1.5 students are, therefore, betwixt and between their ethnic cultures at home and the American culture surrounding them. Although the range of characteristics and experiences can be wide-ranging, what is clear is that Generation 1.5, especially those who are college students, face major obstacles in writing competencies in the university curricula (i.e., academic writing) [14][10][4][15][16]. It is important, then, to contextualize this notion of Generation 1.5 in terms of our students at SJSU. As Harklau, Losey, and Siegal [14] explain, "Because of their unique status, not recent immigrants and not mainstream American students, they [Generation 1.5] often fall through the cracks and find it extremely difficult, if not impossible, to succeed in college” (p. 1). In fact, at most universities like SJSU, what is made available to students in terms of writing assistance falls into one of two 
categories: writing instruction based on English fluency (for U.S. born and adapted students) and writing instruction based on English language learning (for ESL students). Because a significant number of students at SJSU fall into the Generation 1.5 designation, it is crucial that SJSU focus on improving its writing resources, models, curriculum, and instructional approaches in context of and response to Generation 1.5.

\section{ENGR 81W}

For the last eleven years, the college offered an optional class, ENGR 90W, to students who are not proficient in writing. The goal of ENGR $81 \mathrm{~W}$ is to improve on the framework of ENGR 90W and cater to needs of our project's target population. ENGR 81W is a one-unit writing lab designed to improve students' writing skills and ultimately enable them to succeed on the Writing Skills Test and ENGR 8 and ENGR 10. Students enrolled in ENGR 81W meet once a week for two hours and are given weekly writing activities that include: instruction in basic grammar, proofreading, and editing. Weekly assignments promote students frequently engage and learn from their challenges in writing. In addition, students are expected to study and practice exercises. This additional coursework provides practice in using correct grammar, spelling, punctuation, sentence structure, and paragraph structure. Students have the opportunity to develop technical communication skills through written assignments that include vocabulary handouts, short essays, memos, and letters, along with various in class activities and assignments. Other assignments include aural activities, learning methods for effective Power Point presentations, and a group presentation.

\section{Methodology}

Overall, there were 470 incoming freshmen in the College of Engineering in Fall 2012 and 857 in Fall 2013. Because of a university-wide initiative, the President decided in Fall 2013 to admit more students to the Colleges of Engineering and Business. The California State University system-wide placement testing program in basic reading, writing, and mathematics skills consists of the English Placement Test (EPT) and the Entry Level Mathematics (ELM) examination. Students who do not earn a score that indicates they are ready for college level English must enroll in the remedial course(s) as determined by their score. Placement into an English course is based on the student's EPT score as follows:

\begin{tabular}{|l|l|l|}
\hline EPT Scores & First Semester & Second Semester \\
\hline $0-138$ & LLD 1 & LLD 2 or English 1A \\
\hline $139-146$ & LLD 2 & English 1A \\
\hline $147-180$ & English 1A & \\
\hline
\end{tabular}

As a part of our AANAPISI project, the College of Engineering selected freshmen from the classes of Fall 2012 and Fall 2013 as the pilot group. These students were selected based on their English Placement Test (EPT) scores. The EPT is designed to assess the level of reading and writing skills of entering lower-division students so that they can be placed in appropriate English composition courses. Students who receive low scores on the EPT are designated Englishremedial and are placed in remedial courses. For the purposes of this study, we pulled remedial students for the experimental group and the comparison group. Students in the experimental 
group were enrolled in ENGR 81W (formerly ENGR 90W). Of the 106 remedial engineering freshmen, 63 enrolled in ENGR 81W in Fall 2012. There were 227 incoming engineering freshmen in Fall 2014 who were remedial in English; of these students, 135 enrolled in ENGR $81 \mathrm{~W}$. The research questions for this study are shown below.

\section{Research Questions}

Research Question 1: Do the students who took ENGR 81W have higher levels of achievement as measured by GPA, probation, and disqualification when compared to students who did not take ENGR 81W?

Research Question 2: Are there differences in achievement of remedial students when analyzed by ethnicity?

In this study, we used transcript analysis of the all the English remedial engineering students from Fall 2012 and Fall 2013 to determine their achievement of specific levels after four semesters. As shown in Table 1, there were a large number of remedial English students among the incoming freshmen in both Fall 2012 and 2013, with an increase in both the number of students and the number of remedial English students in 2013. The percent and numbers of remedial English students vary by discipline from none in Biomedical and Materials Engineering to $60 \%$ of the incoming Industrial Technology freshmen. There were differences in ethnicity as well (see Table 2). The largest ethnicities among the remedial English engineering freshmen were African-American, Asian, and Latino/a. At SJSU, African-American and Latino/a students have lower retention and graduation rates.

Table 1. Incoming Fall 2012 Freshmen remedial in English by Major

\begin{tabular}{|l|c|c|c|c|c|c|c|c|}
\cline { 2 - 9 } \multicolumn{1}{l|}{} & \multicolumn{4}{c|}{ Fall 2012 } & \multicolumn{4}{c|}{ Fall 2013 } \\
\hline & $\begin{array}{c}\text { Total } \\
\text { Freshmen }\end{array}$ & $\begin{array}{c}\text { Total } \\
\text { Number } \\
\text { Engr } \\
\text { Remed }\end{array}$ & $\begin{array}{c}\text { Engr } \\
\text { Remed } \\
\text { Taking } \\
\text { Engr 81W }\end{array}$ & $\begin{array}{c}\text { Engr Rem } \\
\text { Eot taking } \\
\text { Engr 81W }\end{array}$ & $\begin{array}{c}\text { Total } \\
\text { Freshmen }\end{array}$ & $\begin{array}{c}\text { Total } \\
\text { Number } \\
\text { Engr } \\
\text { Remed }\end{array}$ & $\begin{array}{c}\text { Engr } \\
\text { Remed } \\
\text { Taking } \\
\text { Engr 81W }\end{array}$ & $\begin{array}{c}\text { Engr Rem } \\
\text { Not taking } \\
\text { Engr 81W }\end{array}$ \\
\hline Aerospace Engr & 43 & $8(18.6 \%)$ & 5 & 3 & 67 & $14(20.9 \%)$ & 7 & 7 \\
\hline Aviation & 28 & $8(28.6 \%)$ & 1 & 7 & 24 & $8(33.3 \%)$ & 0 & 8 \\
\hline Biomedical Engr & 6 & $0(0 \%)$ & 0 & 0 & 48 & $5(10.4 \%)$ & 4 & 1 \\
\hline Chemical Engr & 22 & $3(13.6 \%)$ & 2 & 1 & 32 & $9(28.1 \%)$ & 6 & 3 \\
\hline Civil Engr & 15 & $5(33.3 \%)$ & 4 & 1 & 91 & $24(26.4 \%)$ & 17 & 7 \\
\hline Computer Engr & 149 & $36(24.2 \%)$ & 23 & 13 & 173 & $54(31.2 \%)$ & 34 & 20 \\
\hline Electrical Engr & 71 & $19(26.8 \%)$ & 14 & 5 & 92 & $25(27.2 \%)$ & 18 & 7 \\
\hline General Engr & 48 & $7(14.6 \%)$ & 4 & 3 & 110 & $31(28.2 \%)$ & 21 & 10 \\
\hline Industrial Tech & 5 & $3(60 \%)$ & 1 & 2 & 11 & $4(36.4 \%)$ & 2 & 2 \\
\hline Indus/Syst Engr & 13 & $5(38.5 \%)$ & 3 & 2 & 8 & $2(25 \%)$ & 1 & 1 \\
\hline Materials Engr & 6 & $0(0 \%)$ & 0 & 0 & 4 & $2(50 \%)$ & 0 & 2 \\
\hline Mechanical Engr & 31 & $4(12.9 \%)$ & 1 & 3 & 150 & $37(24.7 \%)$ & 21 & 16 \\
\hline Software Engr & 33 & $7(21.2 \%)$ & 4 & 3 & 47 & $12(25.5 \%)$ & 4 & 8 \\
\hline Total & 470 & 106 & 63 & 43 & 857 & 227 & 135 & 92 \\
\hline
\end{tabular}


Table 2. Distribution of English Remedial Engineering Freshmen by Ethnicity

\begin{tabular}{|l|c|c|c|c|c|c|c|c|}
\cline { 2 - 9 } \multicolumn{1}{c|}{} & \multicolumn{4}{c|}{ Fall 2012 } & \multicolumn{4}{c|}{ Fall 2013 } \\
\hline Ethnicity & $\begin{array}{c}\text { All ENGR } \\
\text { Freshmen }\end{array}$ & $\begin{array}{c}\text { Total } \\
\text { Number } \\
\text { Engr } \\
\text { Remed }\end{array}$ & $\begin{array}{c}\text { Engr } \\
\text { Remed } \\
\text { Taking } \\
\text { Engr 81W }\end{array}$ & $\begin{array}{c}\text { Engr Rem } \\
\text { Not taking } \\
\text { Engr 81W }\end{array}$ & $\begin{array}{c}\text { All ENGR } \\
\text { Freshmen }\end{array}$ & $\begin{array}{c}\text { Total } \\
\text { Number } \\
\text { Engr } \\
\text { Remed }\end{array}$ & $\begin{array}{c}\text { Engr } \\
\text { Remed } \\
\text { Taking } \\
\text { Engr 81W }\end{array}$ & $\begin{array}{c}\text { Engr Rem } \\
\text { Not taking } \\
\text { Engr 81W }\end{array}$ \\
\hline AfAm & 15 & $8(53.3 \%)$ & 4 & 4 & 36 & $12(33.3 \%)$ & 7 & 5 \\
\hline Asian & 215 & $50(23.3 \%)$ & 33 & 17 & 368 & $\begin{array}{c}112 \\
(30.4 \%)\end{array}$ & 70 & 42 \\
\hline PacIs & 2 & $1(50 \%)$ & 1 & 0 & 8 & $2(25 \%)$ & 1 & 1 \\
\hline Latino/a & 98 & $34(34.7 \%)$ & 21 & 13 & 193 & $78(40.4 \%)$ & 46 & 32 \\
\hline White & 85 & $7(8.2 \%)$ & 3 & 4 & 149 & $16(10.7 \%)$ & 11 & 5 \\
\hline Foreign & 17 & $0(0 \%)$ & 0 & 0 & 52 & 0 & 0 & 0 \\
\hline Other & 38 & $6(15.8 \%)$ & 1 & 5 & 51 & $7(13.7 \%)$ & 0 & 7 \\
\hline Total & 470 & 106 & 63 & 43 & & 227 & 135 & 92 \\
\hline
\end{tabular}

\section{Student Achievement}

Overall, remedial students struggled in their courses at SJSU during their first two years. For the Fall 2012, 17 of the remedial English engineering students were disqualified and an additional 13 left SJSU. For the Fall 2013 cohort, 15 of the remedial English engineering students were disqualified and an additional 13 left SJSU. There was no significant difference in disqualification or leaving when comparing students who took ENGR 81W to those who did not. Table 3 displays the grades in English 1A (the first academic writing class) for the students. Students in the ENGR $81 \mathrm{~W}$ class were more likely to earn grades of $\mathrm{C}$ or better on their ENGL 1A class than students who did not take the ENGR 81W class; 76\% of the Fall 2012 and Fall 2013 students who took ENGR 81W earned passing grades in ENGL 1A compared to 71.8\% of students who did not take ENGR 81W.

Table 3. Distribution of English 1A grades

\begin{tabular}{|l|c|c|c|c|c|c|}
\cline { 2 - 7 } \multicolumn{1}{c|}{} & \multicolumn{2}{c|}{ Fall 2012 } & \multicolumn{2}{c|}{ Fall 2013 } & \multicolumn{2}{c|}{ Total } \\
\hline Grade Engl 1A & $\begin{array}{c}\text { Engr 81W } \\
\text { students }\end{array}$ & $\begin{array}{c}\text { Non-Engr } \\
81 \mathrm{~W} \\
\text { students }\end{array}$ & $\begin{array}{c}\text { Engr 81W } \\
\text { students }\end{array}$ & $\begin{array}{c}\text { Non-Engr } \\
81 \mathrm{~W} \\
\text { students }\end{array}$ & $\begin{array}{c}\text { Engr 81W } \\
\text { students }\end{array}$ & $\begin{array}{c}\text { Non-Engr } \\
81 \mathrm{~W} \\
\text { students }\end{array}$ \\
\hline $\mathrm{A}+, \mathrm{A}, \mathrm{A}-$ & 4 & 2 & 10 & 6 & 14 & 8 \\
\hline $\mathrm{B}+, \mathrm{B}, \mathrm{B}-$ & 26 & 18 & 67 & 42 & 93 & 60 \\
\hline $\mathrm{C}+, \mathrm{C}$ & 17 & 13 & 28 & 16 & 45 & 29 \\
\hline Total C and above & $\mathbf{4 7}$ & $\mathbf{3 3}$ & $\mathbf{1 0 5}$ & $\mathbf{6 4}$ & $\mathbf{1 5 2}$ & $\mathbf{9 7}$ \\
\hline C- or lower & 6 & 1 & 11 & 10 & 17 & 11 \\
\hline Did not take & 10 & 9 & 19 & 18 & 29 & 27 \\
\hline Total & 63 & 43 & 135 & 92 & 198 & 135 \\
\hline
\end{tabular}

When we compared the four-semester GPAs of these two cohorts, we found differences between the two groups. From this analysis, we excluded students who were disqualified or left SJSU before their fourth semester. Students who took ENGR 81W (see Table 4) has higher foursemester GPAs than students who did not take ENGR 81W although the difference was not significant ( $\mathrm{t}=0.12)$. We have, however, seen in increase in comparison to the previous cohort, which was $t=0.17$. While neither number is considered significant, it does warrant further study. 
Table 4. Four semester GPAs of students

\begin{tabular}{|l|c|c|r|r|r|c|}
\cline { 2 - 7 } \multicolumn{1}{c|}{} & \multicolumn{2}{c|}{ Fall 2012 } & \multicolumn{2}{c|}{ Fall 2013 } & \multicolumn{2}{c|}{ Total } \\
\hline 4 semester GPA & $\begin{array}{c}\text { Engr 81W } \\
\text { students }\end{array}$ & $\begin{array}{c}\text { Non-Engr } \\
81 \mathrm{~W} \\
\text { students }\end{array}$ & $\begin{array}{c}\text { Engr 81W } \\
\text { students }\end{array}$ & $\begin{array}{c}\text { Non-Engr } \\
81 \mathrm{~W} \\
\text { students }\end{array}$ & $\begin{array}{c}\text { Engr 81W } \\
\text { students }\end{array}$ & $\begin{array}{c}\text { Non-Engr } \\
81 \mathrm{~W} \\
\text { students }\end{array}$ \\
\hline 3.0 and above & 17 & 7 & 31 & 16 & 48 & 23 \\
\hline $2.5-2.99$ & 18 & 14 & 53 & 32 & 71 & 46 \\
\hline $2.0-2.49$ & 9 & 10 & 23 & 20 & 32 & 30 \\
\hline Below 2.0 & 3 & 2 & 6 & 4 & 9 & 6 \\
\hline Total & 47 & 33 & 113 & 72 & 160 & 105 \\
\hline
\end{tabular}

We then investigated whether there were differences in student achievement among Engineering freshmen when comparing ethnicities. As shown in Table 2, most of the remedial English Engineering freshmen at SJSU were under-represented minority (URM) students. Overall, 93 of the 106 remedial English students in Engineering were URM students (87.7\%) in Fall 2012 and 204 out of 227 (90\%) were URM students in Fall 2013.

An analysis of the ethnicities of the students shows that the two largest ethnic groups represented among the English remedial Engineering freshmen were Asian and Latino/a. Therefore, we analyzed the four-semester GPA of students from these ethnic groups (see Table 5). As shown in Table V, Latino/a students had lower four semester GPAs than Asian students. The average foursemester GPA of Asian students who took ENGR 81W was 2.81 compared to 2.73 of the students who did not take ENGR 81W. For Latino/a students, the average four-semester GPA of students who took ENGR $81 \mathrm{~W}$ was 2.64 compared to 2.6 of the students who did not take ENGR $81 \mathrm{~W}$.

Table 5. Four semester GPAs of students by Ethnicity

\begin{tabular}{|l|c|c|c|c|c|c|}
\hline & \multicolumn{2}{|c|}{ L semester GPA } & \multicolumn{2}{c|}{$\begin{array}{c}\text { Non-Engr 81W } \\
\text { Engr 81W students }\end{array}$} & \multicolumn{2}{c|}{$\begin{array}{c}\text { All Engr Remedial } \\
\text { students }\end{array}$} \\
\hline & Asian & Latino/a & Asian & Latino/a & Asian & Latino/a \\
\hline 3.0 and above & 27 & 15 & 14 & 5 & $41(29.9 \%)$ & $20(24.1 \%)$ \\
\hline $2.5-2.99$ & 39 & 19 & 21 & 12 & $60(43.8 \%)$ & $31(37.3 \%)$ \\
\hline $2.0-2.49$ & 19 & 14 & 13 & 11 & $32(23.4 \%)$ & $25(30.1 \%)$ \\
\hline Below 2.0 & 1 & 6 & 3 & 1 & $4(2.9 \%)$ & $7(8.4 \%)$ \\
\hline Total & 86 & 54 & 51 & 29 & 137 & 83 \\
\hline
\end{tabular}

\section{Student Surveys about ENGR 81WAssessment}

Student assessment of ENGR 81w was conducted utilizing a post survey on Survey Monkey in Fall 2012. The survey consisted of 25 questions focused on demographic and self-assessment questions. Students were asked to self-assess their reading comprehension skills before the workshop, during the workshop and afterwards. As well, students were asked to self-assess the courses writing, grammar and vocabulary activities. Oral communication and listening abilities were also investigated in our post-survey. Out of 65 students, 34 responded to the survey, with some students who did not respond to every question.

For the writing activities section, students were asked ten questions based on how they thought the class helped them prepare for writing activities in the future. The questions were rated on a scale of one to five, with one being "the class was not helpful at all” and five being "the class was 
extremely helpful.” As shown in Figure 2, the average response was between three and four, indicating that the majority of the students found the class to be moderately helpful.

Next, students were asked ten questions based on how they felt the course prepared them for grammar and vocabulary activities. The questions were rated on a scale of one to five, with one being "the class was not helpful at all” and five being "the class was extremely helpful." As shown in Figure 3, the average student response fell between 3 and 4, showing that the students found the class to be moderately helpful.

Figure 2.

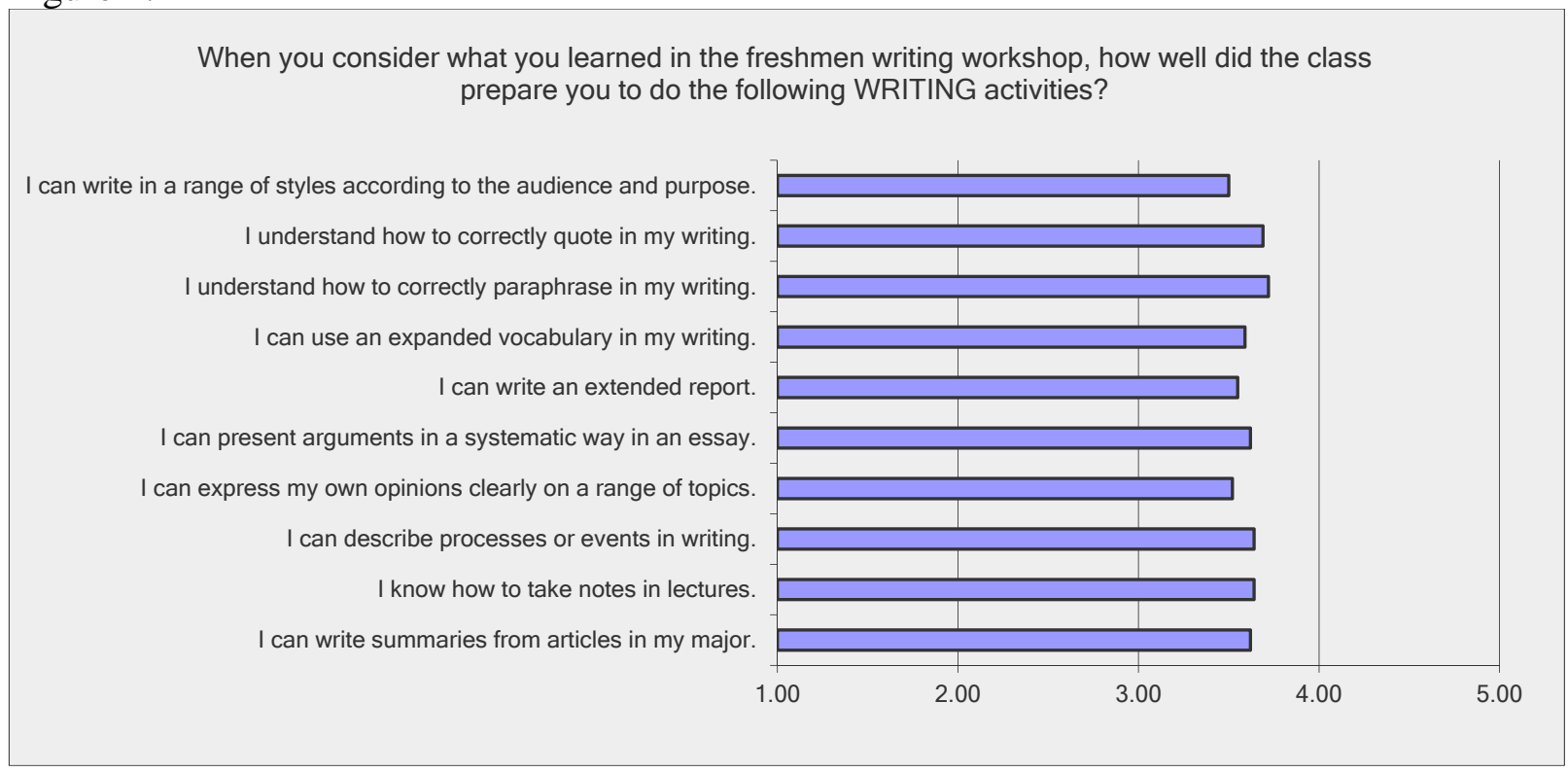

Figure 3.

When you consider what you learned in the freshmen writing workshop, how well did the class prepare you to do the following GRAMMAR AND VOCABULARY activities?

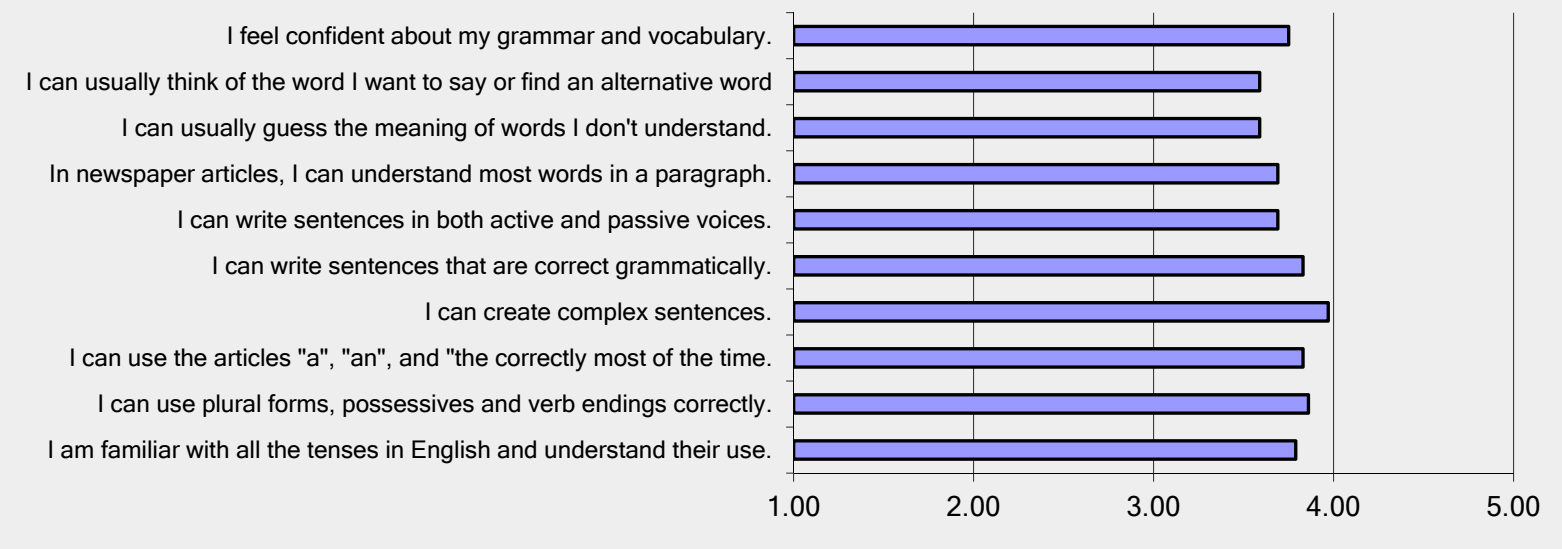

Based on the responses given, the majority of the students found that this course was helpful in preparing them for future writing activities. The students were also questioned on how well the 
class helped prepare them for reading and listening activities. The results were very similar to the writing and grammar and vocabulary responses, with the average student response falling between three and four on these questions as well.

\section{Summary}

As a part of an ongoing five-year Department of Education project, we have been conducting a study on remedial students enrolled in ENGR 81W. Following a restructuring and formatting of ENGR 90w course content, ENGR 81W offers students with more engaging and interactive coursework. Based on our assessment, students who took ENGR 81W (see Table IV) has moderately higher four-semester GPAs than students who did not take ENGR 81W although the difference was not significant $(\mathrm{t}=0.13)$. Also, there was a difference in the achievement of URM students in this class. For both Asian and Latino/a students, taking ENGR 81W was correlated with a modest increase in four-semester GPA. While not a significant increase, a single writing class was helpful for some Generation 1.5 students' long-term academic success. Unfortunately, despite the fact that students can repeat ENGR 81W, few students do so. In order to continue to help these students from slipping through the cracks of our educational system more steps may need to be implemented, but this class is helpful in going in the right direction.

\section{Acknowledgements}

This work was funded through the Asian American Native American Pacific Islander Serving Institutions (AANAPISI) Project at SJSU, which is funded through the U.S. Department of Education (P382B110017). Through this grant, SJSU seeks to improve the writing skills of Asian American, Generation 1.5, and other Under-Represented Minority (URM) students. The author would like also to acknowledge the assistance of Matthew Casey and Mikeal Tadeo in the development of this paper.

\section{References}

1 Singhal, M. (2004). Academic writing and generation 1.5: Pedagogical goals and instructional issues in the college composition classroom. The Reading Matrix, 4(3).

2 Peters, J. (2009). Engaging grammar lessons to give generation 1.5 writers a voice. CATESOL Conference, April 17, 2009. Available: http://www.sfsu.edu/ lac/EngagingGrammarLessons.pdf

3 Murie, R., \& Fitzpatrick, R. (2009). Models for building academic literacy and acculturation. In M. Roberge, M. Siegal, \& L. Harklau (Eds.), Generation 1.5 in college composition: teaching academic writing to U.S. educated learners of ESL (Chapter 11, pp. 153-169). New York: Routledge.

4 Rumbaut, R. G., \& Ima, K. (1988). The adaptation of Southeast Asian refugee youth. A comparative study. Final Report to the U.S. Department of Health and Human Services.

5 Rumbaut, R. (2004). Ages, life stages, and generational cohorts: Decomposing the immigrant first and second generations in the United States. International Migration Review, 38(3), 1160-1205.

$6 \quad$ National Center for Educational Statistics, Available: http://nces.ed.gov/programs/coe/2010/section1/indicator05.asp

7 California Department of Education, Dataquest, http://www.cde.ca.gov/ds/sd/cb/dataquest.asp

8 Reid, J. (1997). Which non-native speaker? Differences between international students and U.S. resident (language minority) students. New Directions for Teaching and Learning, 70, 17-27. 
Mott-Smith, J. (2009). Responding to high-stakes writing assessment. In M. Roberge, M. Siegal, \& L. Harklau (Eds.), Generation 1.5 in college composition: teaching academic writing to U.S. educated learners of ESL (Chapter 9, pp. 120-134). New York: Routledge.

10 Roberge, M. M. (2003). Academic literacy scaffolds for Generation 1.5 students. Paper presented at the 37th Annual TESOL Convention, Baltimore, MD.

11 Goen-Salter, S., Porter, P., \& vanDommelen, D. (2009). Working with Generation 1.5. Pedagogical principles and practices. In M. Roberge, M. Siegal, \& L. Harklau (Eds.), Generation 1.5 in college composition: teaching academic writing to U.S. educated learners of ESL (Chapter 16, pp. 235-259). New York: Routledge.

12 Schwartz, G. G. (2004). Coming to terms: Generation 1.5 students in mainstream composition. The Reading Matrix, 4(3), 40-57.

13 Roberge, M. (2002). California's generation 1.5 immigrants: What experiences, characteristics and needs do they bring to our classrooms? The CATESOL Journal, 14(1), 107-130.

14 Harklau, L., Losey, K. M., \& Siegal, M. (1999). Generation 1.5 meets college composition: issues in the teaching of writing to US-educated learners of ESL. Mahwah, NJ: Lawrence Erlbaum.

15 Thonus, T. (2003). Serving Generation 1.5 Learners in the University Writing Center. TESOL Journal, 12(1), $17-2$

16 Valdés, G. (1992). Bilingual minorities and language issues in writing. Written Communication, 9, 85-136. 